\title{
Pollution indicators and pathogenic microorganisms in wastewater treatment: Implication on receiving water bodies
}

\author{
Tomilola Debby Olaolu ${ }^{1}$, Oghenerobor Benjamin Akpor ${ }^{2,}$, , Charity Omeche Akor ${ }^{2}$ \\ ${ }^{1}$ Biochemistry Unit, Department of Biological Sciences, Landmark University, Omu-Aran, Kwara State, Nigeria \\ ${ }^{2}$ Microbiology Unit, Department of Biological Sciences, Landmark University, Omu-Aran, Kwara State, Nigeria \\ Email address: \\ Olaolu.tomilola@1mu.edu.ng (T. D. Olaolu), akpor.oghenerobor@1mu.edu.ng (O. B. Akpor), omeche.charity@1mu.edu.ng (C. O. Akor)
}

\section{To cite this article:}

Tomilola Debby Olaolu, Oghenerobor Benjamin Akpor, Charity Omeche Akor. Pollution Indicators and Pathogenic Microorganisms in Wastewater Treatment: Implication on Receiving Water Bodies. International Journal of Environmental Protection and Policy.

Vol. 2, No. 6, 2014, pp. 205-212. doi: 10.11648/j.ijepp.20140206.12

\begin{abstract}
There is the indication that human deaths as a result of water-borne diseases exceed five million people per year, with over half of the diseases being microbial intestinal infections, especially cholera and diarrhea. A number of pathogenic microorganisms, regarded as water pollution indicators have been observed as the agents of such. These water pollution indicators are present in feces, sewage and can survive as long as pathogenic organisms. These pathogenic microorganisms cause several waterborne infections and diseases like bacterial (cholera, salmonellosis, shigellosis and several diseases associated with pathogenic strains of E. coli), viral (ranging from a mild febrile illness to myocarditis, meningoencephalitis, poliomyelitis, herpangina, hand-foot-and mouth disease and neonatal multi-organ failure), protozoan (cryptosporidiosis, diarrhea encaphilitis, giardiasis, amoebiasis) and fungal (candidiasis, blastomycosis, cryptococcusis, aspergilosis). These biological contaminants that cause several water-borne diseases can however be removed from water through physical (ultraviolet radiation, solar radiation and boiling) and chemical disinfection methods (chlorination, chloramination and ozonation). The aim of this paper was to review the microbial indicators and pathogenic microorganisms in water and wastewater. The paper also discussed the treatment strategies for microbial-contaminated water and wastewaters.
\end{abstract}

Keywords: Pollution, Wastewater, Pathogens, Microbial Indicators

\section{Introduction}

Untreated and improperly treated wastewater is known to contain pathogens which can cause disease outbreak, hence the need for adequate treatment before discharge into receiving water bodies. The treatment of wastewater is carried out to minimize and eliminate potential health risks. The major groups of pathogens that are of importance to wastewater are either bacteria, viruses, fungi or protozoa (FAO, 1993).

Bacteria, which are the most common pathogens in water, gain entrance into water mostly through fecal contamination (Sharma, 2013). Pathogenic or potentially pathogenic bacteria are normally absent from a healthy intestine unless infection occurs. In the case of an infection, large numbers of pathogenic bacteria will be passed in the faeces. Bacterial pathogens cause typhoid, paratyphoid and other Salmonella type diseases. Some of the bacteria pathogens that are found in wastewater include Salmonella, Shigella, pathogenic strain of Escherichia coli, Yersinia, Campylobacter, Vibrio (Bitton, 2005; Cabral, 2010). Viruses are reported to be the most hazardous pathogens found in wastewater. They are more resistant to treatment, more infectious and difficult to detect in wastewater. Their entrance into water is also through fecal contamination. The viral pathogens that are of importance in wastewater are enteroviruses (including polioviruses), hepatovirus, reoviruses and diarrhoea-causing viruses, especially rotavirus (Bosch, 1998). In the case of protozoa, their detection in wastewater is often as cysts and oocysts. Many species of protozoa can infect humans through ingestion, causing diarrhea and dysentery. The two major protozoan pathogens in water are Cryptosporidium and Giardia (FAO, 1993; Toze, 1997; Yates, 2013).

Since there is a wide range of pathogens that are present in 
wastewater and owing to the inherent difficulties of analysis, thus making the direct determination of the numbers impractical on a routine basis, the microbiological analysis of water depends majorly on detecting the presence of indicator organisms. Indicator organisms are present in large numbers in wastewater, although they may not necessarily be pathogenic. Their detection suggests that human contamination of the water has occurred and that more dangerous organisms could be present. An indicator organism should be applicable in all types of water, always be present or absent when pathogens are present or absent, respectively and should lend itself to routine quantitative testing procedures without interference from or confusion of results because of extraneous organisms. Most indicator organisms are are present in feces and sewage and can survive as long as pathogenic organisms. The major factors that are considered in classifying an organism as an indicator organism includes its association with fecal contamination, its relationship with the pathogen concerned and efficient and simple testing procedures. Indicator organisms are therefore referred to as basic tools for the measurement of water quality, they provide evidences for the presence or absence of pathogenic organisms in water (Plutzer and Torokne, 2012; Department of Health, 2013).

The aim of this paper was to review the major pathogenic and indicator organisms that are of importance in wastewater effluents. The paper also reviewed the various treatment methods for the removal of microbial pathogens from wastewater effluents with particular emphasis on the merits and demerits of each treatment method.

\section{Microbial Pathogens in Wastewater}

The major microbial pathogens in water are bacteria, viruses, fungi and protozoan parasites. Bacteria pathogens are mostly present in feces and a wide variety can be present in wastewater due to fecal contamination. The discharge of untreated or inadequately treated wastewater into the environment can have negative impact on human health due to the release of pathogenic microorganisms into water which could lead to serious health diseases (Rosario et al., 2009). Water that is contaminated with microbial pathogens is a medium for several waterborne diseases, such as cholera, typhoid fever, shigellosis, salmonellosis, campylobacteriosis, giardiasis, cryptosporidiosis and Hepatitis A (WHO, 2004). Several pathogenic organisms in contaminated water are the basic causes of gastrointestinal illnesses in human. Some of the pathogens are known to cause several outbreaks of diseases by releasing toxins in the human body (Krauss and Griebler, 2011). The major groups of water borne pathogens and the diseases they cause are shown in Table 1.

\section{Bacterial pathogens}

The major water related diseases caused by bacteria are cholera, salmonellosis and shigellosis. The majority of bacterial pathogens in wastewater are found in the gastrointestinal tract of humans and animals. They mostly belong to the following genera: Vibrio, Salmonella, Shigella,
Leptospira and pathogenic strains of Escherichia coli, Yersinia and Campylobacter (Cabral, 2010; Yates, 2013). These pathogens cause diseases, such as cholera, salmonellosis, shigellosis/bacillary dysentery and diseases caused by pathogenic strains of E.coli.

Table 1. Major Water Borne Pathogens and Diseases they Cause

\begin{tabular}{|c|c|c|}
\hline Microorganisms & Pathogenic organism & Diseases caused \\
\hline Bacteria & $\begin{array}{l}\text { Salmonella } \\
\text { E.coli (enterotoxigenic) } \\
\text { Yersinia } \\
\text { Campylobacter } \\
\text { Vibrio } \\
\text { Leptospira }\end{array}$ & $\begin{array}{l}\text { Typhoid, } \\
\text { bacillary dysentery } \\
\text { Gastroenteritis } \\
\text { Gastroenteritis } \\
\text { Gastroenteritis } \\
\text { Cholera } \\
\text { Leptospirosis }\end{array}$ \\
\hline Viruses & $\begin{array}{l}\text { Polio virus } \\
\text { Rota virus } \\
\text { Hepatitis A virus } \\
\text { Norwalk virus } \\
\text { Adenovirus } \\
\text { Reovirus } \\
\text { Echovirus }\end{array}$ & $\begin{array}{l}\text { Paralysis } \\
\text { Infantile gastroenteritis } \\
\text { Infectious hepatitis } \\
\text { Gastroenteritis } \\
\text { Conjunctivitis } \\
\text { Respiratory disease } \\
\text { Aseptic Meningitis }\end{array}$ \\
\hline $\begin{array}{l}\text { Protozoa, } \\
\text { helminths and } \\
\text { other parasites }\end{array}$ & $\begin{array}{l}\text { Giardia lamblia } \\
\text { Entamoeba coli } \\
\text { Entamoeba histolytica } \\
\text { Cryposporidium parvum } \\
\text { Ascaris lumbricoides } \\
\text { Ancylostoma } \\
\text { Nectar } \\
\text { Trichuris } \\
\text { Tenia solium } \\
\text { Trichuris trichuria }\end{array}$ & $\begin{array}{l}\text { Diarrhea, malabsorption } \\
\text { Diarrhea, ulceration } \\
\text { Amoebic dysentery } \\
\text { Diarrhea } \\
\text { Ascariasis } \\
\text { Anemia } \\
\text { Anemia } \\
\text { Diarrhea, anemia } \\
\text { Teniasis } \\
\text { Trichuriasis }\end{array}$ \\
\hline
\end{tabular}

Source: (Yates, 2013)

Cholera, an infection of the small intestine caused by Vibrio cholera is primarily transmitted through the consumption of contaminated water (Cabral, 2010; Michelle, 2013). The incubation period of the disease ranges from 1-3 days. The disease is characterized by an acute and very intense diarrhea that can exceed one liter per hour. The bacteria secrets exotoxins that attach to the intestinal cells, causing loss of water, potassium, chloride and carbonate ions from the cells of the mucous membrane leading to diarrhea in patient (Farmer and Brenner, 2003; Cabral, 2010).

Salmonellosis is a disease caused by Salmonella species. The two types of salmonellosis caused by these pathogens are typhoid and paratyphoid fever, which are associated with ingestion of fecal-contaminated water and gastroenteritis (Le Minor, 2003; Michelle, 2013). Salmonellosis of newborns and infants presents diverse clinical symptoms, from grave typhoid-like illness with septicemia to mild or asymptomatic infection (Cabral, 2010).

The causative agent of shigellosis in human is Shigella species. The disease transmission through water is due to their high surviving nature. In the epithelial cell of the intestinal tract of humans, Shigella produces a high level of cytotoxic shiga toxin. The incubation period of the disease ranges from 1-4 days and usually begins with fever, anorexia, 
fatigue and malaise (Strockbine and Maurelli, 2005; Emch and Yunus, 2008; Cabral, 2010). .

The groups of pathogenic E. coli which cause diseases in human health include the enterotoxigenic E. coli (ETEC), enterohemorrhagic E. coli (EHEC) and enteroinvasive E. coli (EIEC). The ETEC strains are the common cause of infantile gastroenteritis, commonly associated with children below 5 years of age in developing countries and accounts for several million cases of diarrhea disease and several ten of thousand deaths each year (Bettelheim, 2003; Scheutz and Strockbine, 2005; WHO, 2006; Cabral, 2010). The EHEC strain (serotype 0157:H7) has an incubation period of 3-4 days and symptoms occur for 7-10 days and $2-7 \%$ leads to renal failure. The EIEC strains are like the Shigella. They invade and replicate in the intestinal cells of humans. The disease symptom is characterized by diarrhea, abdominal cramps, vomiting, fever, chills, malaise and also appearance of blood and mucous in stools of patient. They are frequently associated with diseases such as gastroenteritis and enterocolitis dysentery (Bettelheim, 2003; Scheutz and Strockbine, 2005; WHO, 2010).

\section{Viral pathogens}

Viral pathogens, especially the human enteric viruses, which comprise of the highest number of water borne pathogens, have been found in water as a result of fecal contamination. The enteric viruses include the families Picornaviridae (poliovirus, enterovirus, coxsackievirus, hepatitis A virus and echovirus), Caliciviridae, Reoviridae, Adenoviridae, and Coronaviridae (Krauss and Griebler, 2011). Viruses are among the most important and potentially most hazardous pollutants in wastewater. Generally, viruses are indicated to be more resistant to treatment, more infectious, more difficult to detect and require smaller doses to cause infections. The presence of viruses in polluted waters could lead to a broad range of asymptomatic to severe gastrointestinal, respiratory, skin, eye, nose and ear infection. The enteroviruses and adenoviruses are the most common cause of symptoms of illness in healthy individuals and are often present in polluted water (Environmental News Network, 2007). The spectrum of diseases caused by enteroviruses is broad and ranges from a mild febrile illness to myocarditis, meningoencephalitis, poliomyelitis, herpangina, hand-foot-and mouth disease and neonatal multiorgan failure. Most infections, particularly in children, are asymptomatic, but still lead to the excretion of large numbers of the viruses, which may cause clinical disease in other individuals (WHO, 2006). The major disease caused by the enteric virus is acute gastroenteritis in both adult and adolescence. The hepatitis A virus is a very small enteric virus and is transmitted through fecally contaminated water by infected persons. The symptoms of disease include inflamed liver, followed by lassitude anorexia, weakness, fever, jaundice and nausea (Yates, 2013).

\section{Protozoan pathogens}

Protozoa are mostly associated with gastrointestinal disease, dysentery and ulceration of the liver and intestine. Protozoans can cause life threatening diseases in unborn children, immunocompressed individuals and even the elderly. They are also related to diseases, such as plasmodia, schistosomes, giardiasis, amoebiasis, cryptosporidiosis. The presence of free-living amoeba in water can cause severe diseases in man, for example the Naegleria fowleri, which is the primary cause of amoebic meningoencaphalitis (US National Library of Medicine National Institute of Health, 2003).

The most common protozoan pathogens that are reportedly present in wastewater treatment systems are classified into three groups, the flagellates (Peranema), the sarcodines (Arcella, Euglypha) and the ciliates (Trachelophyllum, Litonotus, Aspidisca, Euplotes, Carchesium, Epistylis, Opercularia). Others include the zoonotic Cryptosporidium pavum, Giardia lamblia, Toxoplasma gondiiis, Entamoeba histolystica, and also free-living amoeba species e.g. Acanthamoeba specie and Naegleria fowleri (Amaral et al, 2004; Krauss and Griebler, 2011).

The two most common parasitic protozoa that are found in wastewater are Giardia and Cryptosporidium. When Giardia cysts gain access to the stomach, they adhere to intestinal wall, leading to giardiasis, a disease, though not fatal but is characterized by diarrhea, abdominal cramps, weight loss, nausea and general gastrointestinal distress (Toze, 1997). Similarly, Cryptosporidium parvum is a parasitic protozoan which causes cryptosporidiosis in individuals who have ingested the oocyst in contaminated water (WHO, 2006). When cryptosporidiosis oocysts attach to the gastrointestinal tract of humans, they produce symptoms that include headache, abdominal cramps, nausea, vomiting, diarrhea and fever. Also, Entamoeba hystolistica can cause diarrhea encaphilitis and even dysentery to infected individuals (ExotoxNet, 1997).

\section{Fungal pathogens}

The most common pathogenic fungi that have been isolated from wastewater include species of Aspergillus, Candida, Rhizopus, Penicillium, Drechslera, and Rhodotorula. Several infections that are known to be caused by fungi are classified according to the site of initial infection, which are superficial mycoses, subcutaneous mycoses and systemic mycoses (Faryal and Hameed, 2005; Department of Environmental and Rural Affairs, 2011).

The majority of fungal diseases are mostly related to water used for recreational activities, such as bathing, swimming and washing. Some pathogenic fungal species could cause fatal nervous system infection through constant exposure to fungal spores can also cause respiratory allergies. They could also produce toxins which can be fatal to health when ingested. The diseases caused by fungi are known as mycosis. Most waterborne fungi remain in spore form and immunocompromised individuals are mostly at risk of infection. The major water-related fungal diseases are candidiasis, causeds by Candida albicans, blastomycosis, caused by Blastomyces dermatitidis, cryptococcusis, caused by Crptococcus neoforman, aspergilosis, caused by Aspergillus fumigatus, coccidiomycosis, caused by Coccidioides immitis and paracoccidioidomycoses, caused 
by Paracocciodoides brasiliensis (Warrington, 2011).

\section{Microbial Indicators in Wastewater}

Indicator organisms in wastewater are organisms whose presence suggests the presence of a pathogen in wastewater. The density of an indicator organism is always associated with health hazards and several sources of pollution. It is indicated that for an organism to qualify as an indicator organism of a particular pathogen, it must be continuously and totally related to the source of the pathogen and be abundant enough to provide appropriate and exact mass concentration of the level of pathogen in relation to high risk of illness. Also, an indicator organism should have resistant ability to disinfectants, environmental stress and toxic materials that may be present at the source of the pathogen (Berg, 1978; Galveston Bay Centre, 2002).

Bacteria indicators are the most important indicators of faecal contamination. These indicators include members of the Enterobacteriacea family, which the total and the fecal coliforms and Escherichia coli. Other bacterial indicators are the fecal streptococci (Streptococcus and Enterocoocus) and Clostridium (Krauss and Griebler, 2011). Generally, the coliforms are gram negative, non-spore forming, oxidase negative, rod shaped, and facultative anaerobic bacteria. They are lactose fermenters with gas production at $35-37$ ${ }^{\circ} \mathrm{C}$ in a medium with bile salt (WHO, 2001). They can thrive at high temperatures, high $\mathrm{pH}$ (up to 9.6), and high salt concentration (up to $6.5 \%$ sodium chloride) and are considered as the most valuable indicator of fecal contamination. Although it is indicated that several species of the four Enterobacteriaceae genera Escherichia sp., Klebsiella sp., Enterobacter sp. and Citrobacter sp. have the ability of giving positive results to tests on environmental waters, the fecal coliform groups are the most widely used. The wide usage of the fecal coliforms is due to their continuous association in fecal waste of man and animals (Cabral, 2010).

In wastewaters, coliforms are seen in abundance, ranging from one to ten million colony forming units in every 100 $\mathrm{mL}$ of primary treated effluent (Galveston Bay Information Centre, 2002). Of the total coliform group, E. coli is the most numerous in mammalian feces, hence is considered the most specific indicator of fecal pollution (National Health and Medical Research Council, 2003). Escherichia coli, a member of the coliform bacteria population which could serve as an indication of fecal contamination, is a natural and essential part of the bacterial flora in the gut of humans and animals. Although some E. coli strains are pathogenic and play roles in intestinal and urinary tract infections, the majorities of E. coli strains are nonpathogenic and reside harmlessly in the colon (Scheutz and Strockbine, 2005).

Another group of indicators of bacterial pollution in water and wastewater are the fecal streptococci. The fecal streptococci are gram-positive, catalase-negative cocci. They consist of two main genera, Enterococcus and Streptococcus, with the Enterococcus indicated to be the preferred indicator of fecal pollution. These organisms are normally found in the gastro-intestinal tract of warm-blooded animals; hence their presence in water indicates fecal contamination. The fecal streptococci and fecal coliform are used to differentiate human fecal contamination from that of warm blooded animals (WHO, 2001). Some species of fecal streptococci include Enterococcus faecalis, Enterococcus faecium, Enterococcus durams, Enterococcus hirae, Streptococcus bovis and Streptococcus equines (Galveston Bay Information Centre, 2002).

Other indicators of bacterial pollution are Clostridium perfringes and Bifidobacteria. Clostridium perfringens is an anaerobic gram-positive, endospore-forming, rod-shaped, sulfite-reducing bacterium. It is found in the colon and represents approximately $0.5 \%$ of the fecal microflora that is commonly found in human and animal feces (Bitton, 2005). The Bifidobacteria are gram positive rods, obligate anaerobes, non-spore formers and non-motile. They are all catalase negative, lactose fermenters and are numerous in feaces of warm-blooded animals. In addition, they are resistant to high temperature environment and can survive longer in an environment than enteric pathogens. Although they are indicated to be highly numbered in human feces, because of their sensitivity to oxygen, their role as useful indicators of fecal pollution in water is limited (Galveston Bay information Centre, 2002).

The major indicators of viral pollution in water and wastewaters are the phages, which are viruses that affect bacteria. The phages are used as models for human enteric viruses in water quality testing (Ashbolt et al., 2001). Generally, phages have been considered microbial indicators of viral pollution as they have similar characteristics with the human enteric virus. The coliphages are viruses that infect coliforms. They are also known as phages of coliforms and have been used to indicate human enteric viruses. The most used coliphages are the T-type (DNA that contains tailed phages) and F-RNA coliphages (RNA phages which can cause infection through the F-Pilli also known as sex factor). Because of their similar morphological structure and behaviour, they have been regarded as the best indicators for fecal pollution than fecal indicator.

Three groups of bacteriophages have been considered as indicators: somatic coliphages, male-specific RNA coliphages (FRNA phages/F+ coliphages) and phages infecting Bacteroides fragilis (Leclerc et al., 2000; Berger and Oshiro, 2002). The somatic coliphages infect mostly $E$. coli, although some can infect other enterobacteriaceae. They have been reportedly used as water quality indicators in estuaries, seawater, freshwater, potable water, wastewater and biosolids (Mocé-Llivina et al., 2003). The F+ coliphages include the families Inoviridae (FDNA) and leviviridae (FRNA). These coliphages are either single-stranded DNA or RNA and infect $E$. coli cells that contain the F plasmid, which is the plasmid that codes for the $F$ or sex pilus to which the phage attach. Their consideration as indicators of wastewater pollution is due to their high numbers in wastewaters and their relatively high resistance to 
chlorination (Nasser et al., 1993; Yahya and Yanko, 1992).

Furthermore, diatoms are used to indicate the general quality of wastewater, with respect to nutrient enrichment. This is because they provide several valuable interpretations with respect to changes in water quality, such as turbidity, conductivity, chemical oxygen demand, biological oxygen demand, dissolved oxygen and chloride (Rey et al., 2002).

\section{Treatment Strategies for Microbial-Contaminated Water and Wastewater}

The two fundamental reasons for the treatment of water and wastewater are to safeguard public health and prevent the pollution of receiving water. The strategies for the treatment of microbial-contaminated water and wastewater are grouped into two: physical (solar radiation and ultraviolet radiation) and chemical disinfection (chlorination, chloramination, ozonation) processes. Each of these processes involves the destruction or inactivation of microorganisms. Although, no disinfection process is known to provide $100 \%$ effectiveness, any good process should be characterized by the ability to penetrate and destroy pathogenic organisms during water treatment process and should be harmless to humans and the environment. Also, it must be cheap to acquire and maintain, easy and safe to handle, store and transport. In addition, during the disinfection process, toxic residuals, mutagens and carcinogens should not be produced (LeChevallier et al., 2004).

\section{Physical disinfection processes}

The two main physical disinfection processes are solar and ultraviolet (UV) radiations. Ultraviolet disinfection involves the exposure of contaminated water to UV light that has been generated by an electronic discharge through mercury vapour The radiations from the UV light penetrates cells of pathogenic organisms in water and destroys their cell genetic material, thereby preventing reproduction (EPA, 1999; Tech Brief, 1999). Ultraviolet radiation is an effective method for the removal of microorganisms, such as Cryptosporidium and Giardia. Because UV radiation is not associated with the production of harmful by-products and known to improve the taste, colour and odour of wastewater, it is considered a safe method of primary disinfection (Trojan Technologies, 2013).

The advantage of a UV disinfection process is that it is an effective means of inactivating virus, spores and cysts. It does not produce toxic by-product and odour and does not also pose any danger of overdosing (Andrew, 2005). Despite the advantages, UV radiation is disadvantageous because it does not leave any residual behind after disinfection; hence there is the possibility of microbial regrowth. Another disadvantage is that because the method lacks any mechanism for determination of its effectiveness, it may not be effective in water that is highly turbid (Environmental Health Directorate, Department of Health, 2010). Generally, UV disinfection method is a recommended treatment method for several pathogenic organisms, such as Burkholderia sp., Clostridium perfringens, Escherichia coli 0157:H7,
Salmonella typhi, Shigella dysenteriaeI, Calciviruses, Hepatitis A virus, Rotavirus, Cryptosporidium sp., Giardia sp.and Toxoplasma gondii (EPA, 2012).

A solar disinfection method is a thermal inactivation and photo-oxidation used to inactivate pathogenic organisms in contaminated water of low turbidity (CDC, 2012a). This method involves the use of the synergetic combination of optical and thermal processes for the treatment of contaminated water that is already contained in a transparent container for the inactivation of microorganisms such as bacteria, virus and protozoa. It is one of the simplest, inexpensive treatments available. It entails filling plastic containers with contaminated water and exposing to the sun for a whole day, thereby exposing microbial cells to ultraviolet radiation from sunlight, which leads to the destruction of their DNA (CDC, 2008; Dawney and Pearce, 2012).

The advantages of this method are its effectiveness against bacteria, protozoa and viruses, its proven reduction of diarrheal disease incidence in users, acceptability to users due to its simplicity and low cost. Also, the method causes minimal change in taste of the water and there is a reduced likelihood of recontamination since the water is served directly from the small, narrow-necked bottles with caps in which it was disinfected (CDC, 2008). The drawbacks of the method are that it requires pretreatment (filtration or flocculation) of waters of higher turbidity and the acceptability concerns because of the limited volume of water that can be treated at once. Also, the length of time required to treat water is long (CDC, 2012b).

\section{Chemical disinfection processes}

There are three commonly used chemical disinfection processes: chloramination, chlorination and ozonation. Chloramination, refers to the use of chlorine and ammonia to disinfect water and is considered one of the best technologies for water disinfection. Chloramines are formed from the combination of chlorine and ammonia. The disinfection method is by the frequent addition of ammonia to water that already contains free chlorine at $\mathrm{pH}$ 8.4. The method is effective and kills microbial cells by penetrating their cell walls, thereby obstructing their metabolism. It is documented that chloramination has served as an effective means for removing microbes such as coliform bacteria, heterotrophic bacteria as well as Legionella bacteria (San Fransisco Public Utilities Commission, 2013). The advantages of chloramination are its ability to improve the odour, taste, smell and flavour of water and it remains active for a very long period of time. The drawback of the use of chloramine for disinfection is it's less effectiveness in killing some pathogenic microorganisms like E. coli, rotavirus and polio (Brockovich, 2010).

In the case of chlorination, the method involves the use of chlorine to disinfect water. The chlorine could either be in solid (calcium hypochlorite) or liquid (sodium hypochlorite) and gas. When added to water, chlorine helps in the reduction of pathogens by affecting the reproduction and metabolism of microorganisms present in the water (Michigan State University, 2010). This method involves introduction of 
chlorine, (about $0.2-0.4 \mathrm{mg} / \mathrm{L}$ ) into contaminated water at $\mathrm{pH}$ of between 5.5-7.5 (Lenntech, 2013). Chlorination disinfection method is a well-established technology and leaves a residual behind, which can prolong disinfection after the treatment process, thereby preventing microbial regrowth The disadvantages of chlorination are the high corrosiveness of chlorine and the production of harmful by-products (trihalomethanes) during disinfection process. Also, apart from the fact that some microorganisms are resistant to chlorine when in low dosage, the method is indicated to increase the chloride content of wastewater (EPA, 1999).

For ozonation, it involves the use of ozone for disinfection. Ozone is considered a very effective oxidizing agent for the treatment of water. The method is indicated to have good bactericidal and virucidal activities. It is considered the most effective disinfectant that can kill microorganisms including bacteria, viruses and protozoans (OzoneFac, 2013). Ozone is considered as the most powerful oxidant which can inactivate microorganisms in contaminated waters and it is more effective than chlorine (Promolife, 2011). The advantage of ozone is that, when compared to chlorination and chloramination, it is considered more effective in killing microorganisms and fast in activity. Also, it is not associated with the production of harmful by-products and helps in the removal of taste and odour from water. The disadvantage is that it that it is not effective in killing cysts and some other larger organisms. Besides, the cost of the equipment used for ozone generation is high and there is always the possibility of microbial re-growth. In addition, apart from the fact that ozone itself can be harmful to human health, the process requires electricity byproducts like bromate which can also cause harm to humans (Guides Network, 2013).

\section{Conclusion}

This paper which was aimed at reviewing the microbial pathogens, indicators of microbial pollutants and treatment strategies for microbial-contaminated water and wastewater has revealed the following:

- The presence of pathogenic organisms in water and wastewater has led to several water-related diseases.

- Because of the enormous time and cost involved in the detection of some of these microbial pollutants, indicator organisms are used.

- The advantages of these indicator organisms are that they are not pathogenic, and directly detect the presence of fecal contamination from warm-blooded animals.

- The various disinfection process enumerated above is beneficial not only to wastewater treatment but also drinking water.

This review was able to provide an insight to the major microbial pathogens and indicators of microbial pollution in water and wastewater. It has also shown the effectiveness of the various treatment processes for the elimination from and inactivation of microbial contaminants in water and wastewater.

\section{References}

[1] Amaral AL, da Motta M, Pons, MN, Vivier H., Roche N, Mota M and Ferreira EC. 2004. Survey of protozoa and metazoan populations in wastewater treatment plants by image analysis and discriminant analysis. Environmetrics, 15: $381-390$

[2] Ashbolt N, Grabow W and Snozzi M. 2001. Water quality: guidance, standards and health: indicators of microbial water quality. IWA Publishing: London

[3] Berg G. 1978. The indicator system. In: Indicators of viruses in water and food (ed. G. Berg). Ann Arbor Science Publishers: Ann Arbor

[4] Berger SB, and Oshiro RK. 2002. Source water protection: Microbiology of source water, pp. 2967-2978, In: Encyclopedia of Environmental Microbiology, (Bitton G ed.). Wiley-Interscience: New York

[5] Bettelheim KA. 2003. The genus Escherichia. In: The Prokaryotes: An Evolving Electronic Resource for the Microbiological Community, 3th ed.; Dworkin, M., Falkow, S.,

[6] Bitton G. 2005. Microbial indicators of fecal contamination: application to microbial source tracking. Department of Environmental Engineering Sciences, University of Florida. Gainesville. Report submitted to the Florida Stormwater Association 719 East Park Avenue, Tallahassee, 32301.

[7] Bosch A. 1998. Human enteric viruses in the water environment: a minireview. International Journal of Microbiology, 1:191-196

[8] Brockovich E. 2010. Chloramination of drinking water. Available at: http://www.ErinBrockovichChloramination.html.

[9] Cabral JPS. 2010. Water Microbiology. Bacterial pathogens and water. International Journal Research and Public Health, 7:3657-3703

[10] CDC. 2008. Household water treatment options in developing countries: solar disinfection. Centre for Disease Control and Prevention (CDC) Documents. Available at www.cdc.gov/../options-sodis.pdf

[11] CDC. 2012a. A guide to drinking water treatment and sanitation for Backcountry and travel use. Center for Disease Control and Prevention (CDC) Publication. Available at: http://www.cdc.gov/healthywater/drinking/public/water_disinf ection.html

[12] CDC. 2012b. Disinfection with chlorine and chloramines.Solar disinfection. Center for Disease Control and Prevention, (CDC) Publication. Available at: http://www.cdc.gov/healthywater/drinking/travel/backcountry _water_treatment.html.

[13] Dawney B and Pearce J. 2012. Optimizing the solar water disinfection (SODIS) method for decreasing turbidity with $\mathrm{NaCl}$. Journal of Water, Sanitation and Hygiene for Development 2(2): 87-94

[14] Department of Health, (2013). Indicator organism. Available at: http://www.baltimorecountymd.gov/Agencies/health/environ mentalhealth/watersampling/terms/term6.html 
[15] Department of Environment Food and Rural Affairs. 2011. A review of fungi in drinking water and the implications for human health. Available at: http://dwi.defra.gov.uk/research/completedresearch/reports/DWI70-2-255.pdf

[16] Emch, M.; Ali, M.; Yunus, M. 2008. Risk Areas and Neighborhood-Level Risk Factors for Shigella dysenteriae 1 and Shigella flexneri. Health Place, 14: 96-105

[17] Environmental News Network. 2007. Viruses in water: The imaginative in pursuit of the fugitive. Society for General Microbiology. Available at: http://www.sgm.ac.uk

[18] EPA. 1999. Ultraviolet disinfection. Water technology fact sheet. EPA water Resources Centre, Washington DC.

[19] EPA. 2012. Containment and disposal of large amounts of contaminated water: A support guide for water utilities. Office of water (4608T). Available at http://www.epa.gov/watersecurity

[20] Exotoxnet. 1997. Microorganisms, Bacteria and Viruses. Available at: http://extoxnet.orst.edu/faqs/extoxnet.htm

[21] FAO. 1993. Quality control of waste water for irrigated crop production:Health risks associated with wastewater. Natural Resources Management and Environmental Development, 2: $10-17$.

[22] Farmer JJ and Hickam-Brenner FW. 2003. The Genus Vibrio and Phtotobacterium. In The Prokaryotes: An Evolving Electronic Resource for the Microbiological Community, electronic release 3.14, 3th ed.; Dworkin, M., Falkow, S., Rosenberg, E., Eds.; Springer-Verlag: New-York

[23] Faryal R and Abdul H. 2005. Isolation and characterization of various fungal strains from textile effluent for their use in bioremediation. Pakistan Journal of Botany, 37(4): 1003-1008

[24] Galveston Bay Centre, (2002). Indicator organisms and water quality criteria. Available at: http://www.Indicator organisms and water quality-2.pdf

[25] Guides Network. 2013. Ozone wastewater treatment. Available at: http://www.waterpollution.org.uk/ozonewastewatertreatment.html

[26] Krauss S, and Griebler C. 2011. Pathogenic Microorganisms and Viruses in Groundwater. Acacatech Materialien, Munchen., 3:10-13

[27] LeChevallier M. and Au K. 2004. Water Treatment and Pathogen Control, achieving Safe Drinking Water. IWA Publishing, Alliance House, London

[28] Leclerc, H., S. Edberg, V. Pierzo, and J. M. Delattre. 2000. Bacteriophages as indicators of enteric viruses and public health risk in groundwaters. Journal of Applied Microbiology, 88: 5-21.

[29] Le Minor P. 2003. The genus Salmonella. In: The Prokaryotes: an evolving electronic resource for the microbiological community, electronic release 3.14, 3th ed.; Dworkin, M., Falkow, S.,

[30] Rey D., Taylor JC, Lass A, van Rensburg L and Vosloo O. 2002. Determining the possible application of diatoms as indicators of general water quality: a comparison with South Africa. Water SA 30(3): 1-11

[31] Michelle K. 2013. Effects of water pollution on human health.
Available at: http://filteredhealth.com

[32] Nasser, AM, Tchorch Y and Fattal B. 1993. Comparative survival of E. coli, F+ bacteriophages, HAV and poliovirus 1 in wastewaters and groundwaters. Water Science and Technology, 27: 401-407

[33] National Health and Medical Research Council (2003). Review of coliforms as microbial indicators of drinking water quality. Australian Government Publication. Available at http://www.nhmrc.gov.au/_files_nhmrc/publications/attachme nts/eh32.pdf

[34] OzoneFac. 2013. Ozone technology: ozone generator summary. Available at: http://www.ozonefac.com

[35] Plutzer J. and Torokne A. 2012. Free-living microscopic organisms as indicators of changes in drinking water quality. Water Practice and Technology, 7(3): 1-13

[36] Promolife. 2011. Ozone water purifiers: ozone water purification an effective water cleaning methods available to remove toxins, and FDA approved for sanitation and water purification. Trustwave's trusted commerce program. Promolife, Inc: Fayatteville

[37] Rosario K, Symonds EM, Sinigalliano C, Stewart J and Breitbart M. 2009. Pepper mild mottle virus as an indicator of faecal pollution. Applied and Environmental Microbiology, 75(22): 7261-7270

[38] San Francisco Public Utilities Commission. 2013. Chloramines. Available at: $\mathrm{http}: / /$ sfwater.org/index.aspx?page $=357$

[39] Scheutz F and Strockbine NA. 2005. Genus Escherichia. In Bergey's Manual of Systematic Bacteriology, 2nd ed.; Brenner, D.J., Krieg, N.R., Staley, J.T., Eds.; Springer: New York, NY, USA, Volume 2, Part B, pp. 607-623

[40] Sharma N. 2013. The health implications of reusing sewage. Available at www.cseindia.org/userfiles/nandini.pdf

[41] Strockbine NA and Maurelli AT. 2005. Genus Shigella. In: Bergey's Manual of Systematic Bacteriology, Volume 2, Part B. (Brenner DJ, Krieg NR, Staley JT, eds.). Springer: New York

[42] Tech Brief. 1999. Ozone: a national drinking water clearing house fact sheet, ultraviolet disinfection.

[43] Toze S. 1997. Literature review for urban water systems multi-divisional research program: Microbial pathogens in wastewater. CSIRO, Australia, 3: 5-10

[44] Trojan Technologies. 2013. UV Disinfection for Drinking Water .Trojan UV- water confidence. Available at: http://trojanUV.com/applications/drinkingwater

[45] US National Library of Medicine National Institute of Health. 2010. Pathogenic human viruses in coastal waters. Available at: http://www.nih.gov.

[46] Warrington P. 2011. Fungi: Aquatic pathogens. Available at: http://www-micro.msb.le.ac.uk/MBChB/6a.html

[47] WHO. 2001. Water Quality: Guidelines, Standards and Health (Fewtrell L and Bartram J), Eds.). IWA Publishing: London

[48] WHO. 2004. Guidelines for Drinking water quality, vol. 1. World Health Organization Press, Geneva 
[49] WHO. 2006. Guidelines for drinking water quality: incorporating first addendum. World Health Organisation Press, Geneva

[50] WHO. 2008. Guidelines for Drinking-water Quality, Incorporating $1 \mathrm{st}$ and 2nd Addenda, Volume 1, Recommendations, 3rd ed.; World Health Organization (WHO) Press, Geneva.

[51] WHO. 2010. Enterotoxigenic Escherichia coli (ETEC). In: Diarrhoeal Diseases. World Health Organization (WHO). Available http://www.who.int/vaccine_research/diseases/diarrhoeal/en/in dex4.html

[52] Yahya MT and Yanko WA. 1992. Comparison of a long-term enteric virus monitoring data base with bacteriophage reduction in full scale reclamation plants. Paper Presented at the International Water Pollution Research Symposium, Washington, DC, May 26-29, 1992.

[53] Yates MV. 2013. Pathogens in reclaimed water. Available at: http://www.geoflow.com/wastewater/pathogens.htm 